\title{
A multikulturalitásra, interkulturalitásra nevelés megjelenése az angolórákon 1-6. osztályig
}

\author{
Szepesi Judit \\ ELTE Gyertyánffy István Gyakorló Általános Iskola
}

\begin{abstract}
A tanulmány azzal a kérdéssel foglalkozik, hogyan jelenik meg a multikulturalitásra/ interkulturalitásra nevelés az 1-6. évfolyamok angolóráin, e téma elméleti hátterét járja körül, beszéla kisgyerekeknyelvtanításának kérdéseirölés rövidáttekintéstadarról, hogy az adott korosztály számára a kultúra tanitása során milyen tartalmakat és hogyan ismertessünk meg tanítványainkkal. A tanulmány gyakorlati része a szerző és tanítójelöltek ötleteiből, tapasztalataiól mutat be példákat a tanórákon megjelenő kultúra tanítására.
\end{abstract}

Kulcsszavak: kultúra, multikulturalizmus, angoltanitás, kisgyermekek, eredeti nyelvi anyagok

A nyelvtanítás az a folyamat, amelynek során diákjainkat arra tanítjuk meg, hogy a célnyelvet a lehető leghatékonyabb módon tudják alkalmazni a legtöbb helyzetben. A tanár feladata, hogy tanítványait a legjobb úton vezesse, illetve juttassa el ehhez a célhoz.

A nyelvtanításnak, így az iskolai nyelvoktatásnak is van azonban egy másik nagyon fontos eleme. Ez nem más, mint az adott nyelven beszélők kultúrájának megismertetése. A nyelv maga és az adott nyelvet beszélő közösség kultúrája együtt alkotja a nyelvtanítás egységét. A kultúra tanítása közelebb hozhat a nyelv jobb elsajátításához és az adott nyelvet beszélők életének, kulturális szokásainak jobb megismeréséhez.

\section{Mi a kultúra?}

A kultúra fogalmának nagyon sok meghatározása létezik. A magaskultúra leginkább a klasszikus művészetekre, irodalomra, zenére, építészetre vonatkozik. Egy másik aspektus szerint a kultúra „a család, a mindennapi élet, az emberi kapcsolatok, az anyagi környezet, a munka és szabadidő, a szokások és intézmények megszervezése és jellege" (Kramsch, 1991. 218. o.).

A kultúra tanításán is túlmutató általános fejlesztési, nevelési cél az idegen nyelvi órákon a napjainkban egyre fontosabbá váló multikulturális/interkulturális fejlesztés.

\section{Mi a multikulturalizmus?}

Mihály Ildikó (2001) meghatározása szerint a multikulturalizmus „kölcsönös együttélést és megértést jelent egyazon társadalomban élő különböző kultúrák között”.

Az Európai Unió szemszögéből nézve a multikulturalitás nemcsak a kultúrák passzív egymás mellett élését, hanem azok aktív együttműködését, egymás segítését, tapasztalatok kölcsönös cseréjét jelenti. Az Európai Unió számára a legnagyobb kihívást a nyelvi és kulturális sokféleség jelenti. Az idegennyelv-oktatás a multikulturális nevelésnek csupán egyik területe. A nyelvoktatás kérdése azonban az egyik legfontosabb az összes terület közül, „hiszen az emberek, népek, kultúrák közeledésének az alapja a kommunikáció” (Tusa, é.n.). 
„A gondolatok, érzelmek teljes körü kifejezéséhez nélkülözhetetlen a beszéd, s a politikai, társadalmi, gazdasági történések, jogszabályok, rendelkezések mind az emberek közti kommunikáció meglétére építenek. Éppen ezért nélkülözhetetlen az idegennyelv-oktatás a multikulturális nevelés területén" (Tusa, é.n.).

A multikulturális oktatás-nevelés többnyire arra törekszik, hogy a tanulók megtanulják kezelni azt a sokszínüséget és különbözőséget, amellyel a nemzetközi közösségekben találkoznak, illetve olyan kognitív, verbális és nonverbális készségeket fejlesszen ki, melyek a különféle kultúrákkal és kulturális csoportokkal való együttmüködést megalapozzák.

\section{A NAT állásfoglalása}

A NAT állásfoglalása szerint „... a tanulók legyenek képesek a saját és más kultúrák különbségeinek, illetve hasonlóságainak értelmezésére, váljanak nyitottabbá és érzékenyebbé más kultúrák irányába. Fontos a pozitív attitűd és motiváció kialakítása a nyelvtanulás, valamint általában más nyelvek és kultúrák megismerése iránt" (NAT, 2012. 10680. о.).

„A nyelv nem választható el attól a kultúrától, amely létrehozta és élteti, ezért a nyelvtanítást mindig össze kell kapcsolni a mindennapi élet kultúrájának megismertetésével, és segíteni kell a tanulókat abban, hogy a szélesebb értelemben vett célnyelvi müveltség elérhetővé váljon számukra. Különösen fontos a tanulás és tanitás során a nyelvtanuló interkulturális tudatosságának kialakitása, fejlesztése. A diák legyen képes felismerni és megérteni a saját és az idegen kultúra jellegzetességeit, a köztük lévő hasonlóságokat és különbségeket, továbbá ismerje és alkalmazza a más kultúrák képviselőivel való kapcsolatteremtéshez szükséges stratégiákat" (NAT, 2012. 10681. o.).

\section{Új kihívások, új módszerek}

Az internet a XX. század fantasztikus találmánya. Ekkora robbanásszerü változást az emberiség életébe nem sok találmány hozott eddig. Megváltoztatta az életünket, sőt fenekestül felforgatott szinte mindent. A világ kinyílt, virtuálisan szinte bárhová eljuthatunk, bármilyen információhoz hozzájuthatunk, találkozhatunk eddig ismeretlen emberekkel, vagy újra felvehetjük a kapcsolatot régóta nem látottakkal. Pillanatok alatt hozzájuthatunk a legfrissebb hírekhez, információkhoz. Játszhatunk, zenét hallgathatunk, filmet nézhetünk, és kicserélhetjük véleményünket, ötleteinket, megoszthatjuk élményeinket. Az internet nyújtotta kínálat végtelennek tünik.

A mai gyerekek, az úgynevezett Z-generáció, már beleszülettek a digitális technológiák világába, s ez részben megváltoztatta tanulási szokásaikat is. Képesek párhuzamosan több dologgal is foglalkozni, egyre kevesebb időt töltenek olvasással, és egyre több időt töltenek internetezéssel, sokkal több információhoz jutnak, és ezeket másképpen dolgozzák fel, mivel másként is gondolkoznak, mint szüleik és tanáraik generációja.

Változtat mindez a gyerekek idegen nyelvi kultúrához való viszonyán? A válasz egyértelmü igen. A gyerekek számára természetes, hogy pillanatok alatt elérhetik kedvenc énekesük dalait, azt a filmet nézhetik meg a neten, amelyikhez kedvük van, sőt, ha vállalkozó szellemủek, eredeti nyelven, esetleg eredeti nyelven való feliratozást olvasva élvezhetik a filmeket, és annyi autentikus, számukra érdekes szöveggel, témával, hírrel találkozhatnak, amennyi bőven kielégítheti kíváncsiságukat. Rengeteg játékprogram érhető el az interneten, amivel a gyerekek előszeretettel játszanak is. Ezek mind angol nyelven adnak utasításokat. Aki szeretne játszani, annak bizony szüksége 
lesz a nyelvi logikájára, memóriájára. De az eredmény sem marad el! A 'gyakorlás' nem csak a játékban tesz jártassá, hanem a használt nyelvben is. Sok tanítványom talált olyan barátokra az internet segítségével, akikkel a nyelvgyakorlás nem tanulás, hanem természetes kommunikáció. Az idegen nyelv mindennapos használatára kialakult igény pedig sokat segít a nyelv gyorsabb és maradandóbb elsajátításában. Aki gyakran tájékozódik az interneten, használja az internet nyújtotta lehetőségeket, az akaratlanul is fejleszti idegennyelv-tudását.

Mindezeket figyelembe véve a nyelvtanulás új fejezete nyílt meg, ami sokat segíthet a diákoknak a sikeres nyelvtanulóvá, nyelvhasználóvá válásban. A nyelvtanulást is segíti, hogy kézzelfoghatóvá válik az idegen nyelv tanulásának célja. Az internet 'tananyagok' óriási tárházát nyújthatja, ami egyúttal hatalmas motiváló erő.

Ezek az új lehetőségek a tanárokat is új kihívások elé állítják. Nem elég csak a régi, jól bevált módszerekkel előrukkolni, szükség van az új technikák alkalmazására is, hogy diákjaink a nyelvórákon is megtalálják a számukra természetes közeggé vált lehetőségeket.

\section{Kisgyerekek nyelvtanítása}

Az imént leírtakkal csak látszólag áll ellentétben az a megállapításom, hogy a kisgyerekkori nyelvtanítás egyik legfontosabb része a személyes kapcsolat, a tanár személye, példája. Emellett tapasztalataim is azt bizonyítják, hogy a kisgyerekek nyelvtanítása csak akkor lehet sikeres, ha életkoruknak megfelelő módon, legfőképpen tevékenykedtetve, játékok segítségével, témákon keresztül fokozatosan és nagyon céltudatosan - nem sürgetve - juttatjuk el őket a megfelelő szintekre. Ebben a folyamatban helye lehet a számítógépek által nyújtott lehetőségeknek, de ezeket a lehetőségeket még később is kamatoztathatjuk. A tanulásnak ebben a szakaszában tehát a személyközpontú nyelvtanítási módoké az elsőbbség!

\section{Mit értünk a kultúra tanításán 6-12 éves tanulók esetében?}

A kultúra 'tanítása' mindennapos tanítási gyakorlatunk egyik legélvezetesebb és legsikeresebb része, mivel hozzásegíti a tanulókat, hogy valami különleges dolog részesének érezhessék magukat.

A gyerekek, mivel természetesen nyitottak és befogadók, igen könnyen tudnak azonosulni bármivel, közel éreznek magukhoz mindent, ami eredeti, mint például a játékok, mondókák, dalok, versek, viccek vagy mesék. A kultúra 'tanítása' két irányba hat: nagyszerü lehetőséget kínál egyrészt a célnyelvi kultúra autentikus tananyagokon keresztül való megismertetésére, másrészt a nyelv természetes módon való elsajátítására.

A kisgyermekkori interkulturális tanítás-tanulás folyamatáról sok hasznos elméleti és gyakorlati tudnivalót oszt meg olvasóival Kovács (2009) vagy Laidlaw (2001) is. A következő tartalmi felosztás Kovács Judit ajánlásai alapján készült (2009. 140. o.).

\section{Mit és hogyan tanítsunk a kultúrán belül?}

\section{Mit tanítsunk?}

- gyermekirodalom: dalok, mondókák, versek, mesék, kiszámolók, viccek stb.,

- mozgásos gyermekjátékok,

- szokások, ünnepek,

- viseletek, 
- jellegzetes ételek, étkezési szokások,

- híres emberek,

- jellegzetes sportok, neves sportolók,

- országismeret: térkép, zászló(k), városok, nevezetességek, híres tájak, országok és jellegzetességeik,

- közlekedési szokások,

- történelem,

- szimbólumok.

2. Hogyan tanítsuk ezeket a tartalmakat?

- tevékenységekbe ágyazva,

- témaként feldolgozva,

- sok vizuális és audiovizuális eszközzel,

- a nyelvi környezet megteremtésével,

- az autentikus tárgyi környezet megteremtésével.

24 éves angol tanítási gyakorlatom alapján sokféle választ és sok példát tudnék adni a „Mit?” és a „Hogyan?" kérdésekre. Amikor ezek a példák megjelennek elöttem, nemcsak régi és új tanítványaimnak az arcát, hangját és játékát tudom felidézni, hanem azt is látom, hogy ezek az órák, feladatok, tevékenységek sikeresek voltak, a gyerekeknek örömet szereztek.

Lényeges megemlíteni, hogy a kultúra tanítása az a terület, ahol a tanulóknak biztosan vannak előzetes ismereteik, izgatottan várnak egy-egy témát, sőt sokszor ők maguk javasolják, miröl tanuljunk az órákon, vagy esetenként beszélgetést kezdeményeznek a célnyelvi kultúra egyik-másik érdekes részletéröl.

A következőkben szeretnék bemutatni néhányat azokból a kultúratanítási ötletekből, konkrét megvalósításukból, amelyek valamilyen okból számomra emlékezetesek maradtak.

\section{Példák a kultúra „tanítására”}

1. Gyermekirodalom: vers

Téma: vers feldolgozása: Eleanor Farjeon: Cats Sleep Anywhere

Korosztály: 4. osztály

Lásd: Függelék

2. Gyermekirodalom: mese

Téma: mese olvasása, feldolgozása: Robin Tzannes: Professor Puffendorf's Secret Potions Korosztály: 5 . osztály

Lásd: Függelék

3. Szokások, ünnepek

Téma: Halloween

Korosztály: 3 . osztály, kezdő szint

Halloween-témaháló: 


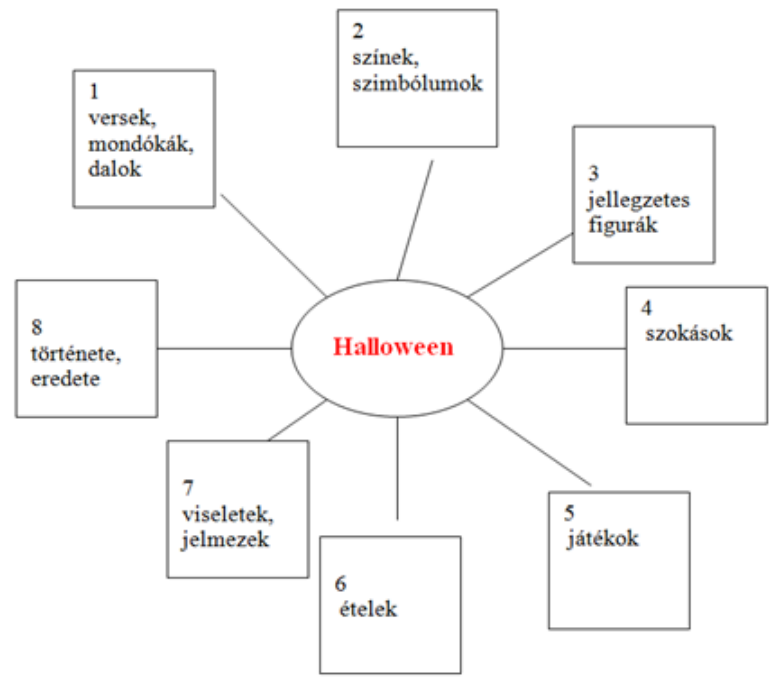

1. ábra: Halloween-témaháló

1. versek, mondókák, dalok: Trick or Treat; Peter, Peter, Pumpkin eater,

2. színek, szimbólumok: fekete, narancssárga, töklámpás

3. jellegzetes figurák, állatok: szellemek, csontvázak, múmiák, boszorkányok, fekete macska, pók, bagoly, béka, denevér, temető, koporsó stb.

4. szokások: töklámpás készítése, Trick or Treat-járás, lakások feldíszítése

5. játékok: apple-bobbing

6. ételek: cukorka, csokoládé, puding

7. viseletek: fekete, narancssárga színü ruhák, jelmezek

8. története, eredete

A Halloweentéma és az azt feldolgozó órák jó példák arra, hogyan történik meg egy tanítási egységen belül a tanulók nyelvi és szociális kompetenciáinak fejlesztése és kulturális ismeretek átadása, valamint elsajátítása. A téma négy tanítási órában került feldolgozásra. Az órák során a tanulók megismerkedtek a szükséges szókinccsel, megtanultak két tradicionális mondókát, a megtanult szókincset értelmes szövegkörnyezetbe ágyazva használták.

Hogy a téma még közelebb kerülhessen a tanulókhoz, egy kreatív, manipulatív feladatot is kaptak, 'töklámpást' készítettek papírból. (Részletes leírás arról, hogyan jelenik meg a kultúra tanítása egy órán: lásd Függelék.)

\section{Szokások, ünnepek}

Téma: Halloweendélután az iskolában

Korosztály: felső tagozatosok

Hagyományosan minden évben Halloween idején iskolánkban egy délutánt töltünk el a halloweeni szokások, hagyományok felelevenítésével, játékkal, versenyekkel. Szintén hagyomány, hogy a délutánt a beöltözött felsősök azzal kezdik, hogy a kisebbeket, alsós társaikat a „Trick or Treat” mondókával ijesztgetik és próbálják rávenni őket arra, hogy cukorkát adjanak nekik. Tapasztalataink szerint a gyerekek ezt a rövid mozzanatot évek múlva is a legjobb emlékeik között őrzik. 
5. Szokások, ünnepek

Téma: Valentin-napi „szívküldi” az iskolában

Korosztály: felső tagozatosok

Több éve már, február 14-én megemlékezünk a brit kultúrának erről a kedves szokásáról iskolánkban. A gyerekek szív alakú papírra üzeneteket írhatnak bárkinek az iskolában, betartva az üzenetküldés ekkor szokásos módját. A leveleket a nap végén kézbesítjük a címzetteknek.

\section{Országismeret}

Téma: Ausztrália

Korosztály: 6. osztály

Ezt a témát öt tanítási órában dolgoztuk fel. Témánk szempontjából a következő fontos lépéseket emelem ki:

\section{1. óra}

- A munka elején készítettünk közösen egy témahálót, amelyre a gyerekek felírták, hogy mit tartanak a témával kapcsolatban fontosnak, mi mindent tudnak róla, és mi az, amit szeretnének megtudni, amiröl szeretnének beszélni, hallani, olvasni.

- Ezután csoportban kaptak a gyerekek egy félig kitöltött térképet Ausztráliáról, amelybe beleírták, illetve a térkép köré rendezték addigi ismereteiket az országról, majd a csoportok megosztották egymással ezeket az ismereteket.

- A következő lépésként részben a tanulók ötletei alapján, részben elöre megtervezve képek segítségével szókincsbővítésre került sor. Néhány jellegzetességet, fontos dolgot képeken, könyvekből megmutattam a tanulóknak. Ezek a vizuális anyagok egy-egy nagyobb témacsoportot képviseltek: például tudnivalók a kontinensröl, az országról, ott élő állatok, növények, az ország természeti földrajza, sport, jellegzetességek stb.

- A szókincs elmélyítésére a tanulók minden új kifejezéshez egy-egy definíciót társítottak a megadott meghatározások közül kooperatív munkaformában.

\section{2. óra}

- Ugyanezt a célt szolgálta az a feladat, amelyben egy dominóelvü („,hear and say") játék keretében a tanulók most már önállóan egy-egy hallott kifejezésre annak meghatározásával, magyarázatával szolgáltak.

- A szókincsfejlesztésnek az ebben az osztályban közkedvelt formája is szerepelt az órák során: a csoportok az általuk választott újonnan tanult szavakhoz definíciókat alkottak (felhasználva az addig gyakoroltakat), majd rejtvényeiket egymásnak feladva versenyeztek.

- A szókincsbővítés egy másik területe a kedvencre, az állatvilág témakörre épült. Ausztrália jellegzetes, különleges állataival ismerkedtek meg, illetve ismertették meg egymást a tanulók különböző feladatok segítségével.

- A következő egység az információszerzésre épült. A csoportok néhány kártyát választottak, amelyek mindegyikén egy-egy kulcskifejezést találtak Ausztráliáról. A teremben, a falakon több lapra kitéve olvashattak a tanulók Ausztráliáról szóló tudnivalókat. A tanulók körbejártak és elolvasták az állításokat, majd megpróbálták kihámozni belőlük, melyik az, amelyik az ő kulcsszavaikat kifejtő információ. Ezeket lejegyezték, majd a csoportok beszámoltak arról, mit találtak.

- Az ezt követő részben a tanulók kiegészíthették térképüket egy-egy általuk fontosnak tartott új információval. 
3. óra

- Következő lépésként a tanulók ugyanezeket az információkat kérdés-felelet formájában kapták meg úgy, hogy a kérdés-felelet párt nekik kellett összeilleszteni.

- A gyerekek párban eldöntötték, hogy saját országukat vagy Ausztráliát képviselik-e egy szerepjátékban, majd az előzőleg begyakorolt kérdések felhasználásával eljátszottak egy ismerkedést és ezen belül országuk bemutatását.

\section{4. óra}

- Vetélkedő keretében a csoportok kérdéseket alkottak, illetve különböző feladatokat terveztek társaik számára a témával kapcsolatban, majd ezeket egy-egy lapra felírva kitették a táblára. A vetélkedő során a csoportok választottak feladatot maguknak a táblára kitettek közül. A vetélkedő előkészítése és a játék maga, amellett, hogy a gyerekek számára élvezetes volt, összefoglalta a tanultakat.

\section{5. óra}

- Otthoni gyűjtőmunkaként a csoportok képeket gyűjtöttek, rajzokat készítettek, rövid magyarázó szövegeket írtak, illetve új információkat kerestek Ausztráliáról. Az órán a csoportok azt az összetett feladatot kapták, hogy egy utazási iroda megbízásából készítsenek egy Ausztráliát bemutató és ausztráliai utazásokat reklámozó posztert, majd a poszter felhasználásával tartsanak egy ismertetőt az országról. A téma lezárásaként minden csoport, amelyik szükségesnek látta, kiegészítette térképét. Ezután a térképeket is és a posztereket is kiállítottuk az osztályban.

\section{Országismeret}

Téma: verseny kerületi iskolák csapatai számára, Anglia / Skócia / Írország...

Korosztály: 6 . osztály

Iskolánkban már többször szerveztünk országismereti versenyt a kerület hatodikosainak. Ezek a versenyek hagyományosan a következő lépésekből állnak:

3 fős csapatok 4 állomáson 4 különböző feladatot oldanak meg.

1. állomás: az előzőleg elkészített poszter bemutatása 1-2 perces angol nyelvü beszámolóval, amiben minden csapattagnak részt kell vennie; a poszter az országgal kapcsolatban tetszőlegesen választott témát mutathat be.

2. állomás: Hol készült a kép? - vetített képek felismerése.

3. állomás: kvízfeladatok.

4. állomás: A versenyzők tartalmas és érdekes programot állítanak össze olyan turisták számára, akik két napot szeretnének eltölteni Londonban stb. és mindenre kíváncsiak.

\section{Tanárjelöltek felkészítése}

Munkámban két különböző, de egymással szorosan összefüggő feladatot látok el. Általános iskolás gyerekeket tanítok angolra, és tanító-, illetve tanárjelöltek angol tanítási gyakorlatát vezetem. Kiemelten fontos, hogy a hallgatók ne csak elméletben tudják, mi az, amit tanítaniuk kell, hanem a gyakorlatban is felkészülhessenek a „Mit?” és a „Hogyan?”-ra egyaránt. Ebben a felkészülési folyamatban a kultúra 'tanítása' kiemelt helyen áll.

Az elmúlt évek során nagyon sok remek példa bizonyította, hogy a 'kistanárok' jól értelmezik a kultúra 'tanítását'. Az általuk tervezett és megtartott órákból egyaránt 
világosan látszik, tudják, milyen módon közelítsék meg az idegen kultúrát, az ismereteket játékba, ezáltal élménybe ágyazva, hogy az a gyerekekben a lehető legjobb és legmélyebb nyomot hagyja.

Néhányat a hallgatók ötletgyűjteményéből is közreadok:

\section{Szokások, ünnepek}

Téma: Hálaadás; Az ünnep története

Korosztály: 4. osztály

A pedagógus a hálaadás történetét ábrázoló képeket ad minden tanulónak. Ezután elmeséli a nagyon egyszerü nyelven megfogalmazott történetet. A tanulók figyelmesen hallgatják, és amikor a tanár a kezükben lévő képről beszél, kiteszik azt a táblára, figyelve az időrendi sorrend betartására (Kordás Imola ötlete).

\section{Szokások, ünnepek}

Téma: Hálaadás; Átkelés az óceánon

Korosztály: 4. osztály

A tanulók szerepkártyákat húznak. A szerepek a következők: Mayflower, Újvilág, sziklák, szigetek. Az Újvilágot játszó tanuló a terem egyik végébe áll, a Mayflowert megszemélyesítő a terem másik végébe bekötött szemmel. A terem maga jelképezi az óceánt. A „sziklák és szigetek” a Mayflower és az Újvilág között tetszés szerint ülve, állva, fekve helyezkednek el.

A hajó feladata, hogy biztonságban átszelje az óceánt, kikerülve az ott lévő akadályokat. A hajó mindig a hozzá legközelebb álló „szikla vagy sziget” instrukcióit követi (Kordás Imola ötlete).

\section{Szokások, ünnepek}

Téma: Hálaadás; Te miért vagy hálás?

Korosztály: 4. osztály

A tanár egy farktollak nélküli pulyka képét helyezi el a táblán. A papírból készült madártollakat a tanulók megkapják, ezekre írják, rajzolják, miért lehetnek hálásak. A feladatot a tanár saját példájával mutatja be. Amikor a gyerekek elkészülnek az írással, rajzzal, a tollakat 'visszaadják a pulykának', miközben elmondják, mi került a tollra (Kordás Imola ötlete).

\section{Szokások, ünnepek}

Téma: Karácsony; Add vissza Rudolf orrát!

Korosztály: 4. osztály

A tanár a táblára kiteszi Rudolf rénszarvas képét, amiről hiányzik a piros orr. Ezután a tanulóknak beköti a szemét, majd mindenki a saját nevével ellátott 'orrot' kap a kezébe. A gyerekek megpróbálják Rudolf orrát a helyére tenni (blu-tack segítségével). A nyertes az, aki a legjobban megközelíti a tökéletes helyet (Kordás Imola ötlete). 
Szepesi Judit

\section{Szokások, ünnepek}

Téma: Karácsony; A Grinch lopott a Mikulástól!

Korosztály: 4. osztály

A tanulók szerepeket választanak: kis Grinchek vagy Mikulás segítői, manók lehetnek. A Mikulástól a Grinchek elloptak sok mindent, a manóknak vissza kell szerezniük ezeket a dolgokat. A Grinchek listát kapnak, amin az általuk ellopott dolgok (szavak/képek) szerepelnek. A manók is kapnak egy-egy listát, amely csupán néhány ellopott tárgyat sorol fel. A cél, hogy a manók mindent visszaszerezzenek. A manók egyik Grinchtől a másikig járva kérdezgetik, nincs-e náluk a keresett tárgy. Ha igen a válasz, a manó kipipálja saját listáján a megtalált tárgyat (Szabó Petra ötlete).

\section{Szokások, ünnepek}

Téma: Karácsony; Mikulás és Rudolf

Korosztály: 4. osztály

A táblán Mikulás és Rudolf formájú két lap van. A tábla egy másik részén, szókártyákon kettejük testrészei vannak felírva. Például: fehér szakáll, piros orr stb. Minden tanuló választ egy kártyát, és a megfelelő testre felrajzolják a kártyán szereplő testrészt. Ezután közösen bemutatják a két alakot (Fekete Ákos ötlete).

\section{Szokások, ünnepek}

Téma: Halloween; Szellemkastély

Korosztály: 4. osztály

A teremben képeket rejtett el előzőleg a tanár, ezeket kell a gyerekeknek megkeresniük. Ha valaki rátalál egyre, sikoltania kell. Amikor társai ezt meghallják, ezt kérdezik: Mit látsz? A válasz: Egy szellemet/ boszorkányt/ szörnyet stb. látok (Kordás Imola ötlete).

\section{Szokások, ünnepek}

Téma: Halloween; Csontváz

Korosztály: 5. osztály

A tanulók mindkét csoportja narancssárga léggömböket kap. Ezeket kell a csoportoknak kipukkasztani, hogy a bennük lévő papírok feladatait elolvashassák. Ha a tanulók teljesítik feladatukat, egy csontváz egy-egy csontját kapják érte. Az a cél, hogy a csapatok össze tudják rakni a saját csontvázukat (Taylor Jennifer ötlete).

\section{Gyermekirodalom: mese}

Téma: Mese eljátszása; Hol van Spot?

Korosztály: 3. osztály

A tanár és a tanulók Spot kutyus keresésére indulnak Sallyvel, Spot mamájával együtt a teremben. Különböző helyeket keresnek fel, ahová a tanár előzőleg más és más berendezési tárgyat ábrázoló képet ragasztott fel. A képek mindegyikén felhajtható kis ajtó van. Ott a tanulók megkérdezik: Spot a ... alatt/ mögött stb. van? Egy tanuló megnézi, valóban ott van-e Spot. A képek alatt egy kivételével nem a kutya, hanem más állat képe látható. Ha nem a kutyát látja a tanuló, társai találgatással próbálják kitalálni, melyik állat lehet az (Szigeti Anna ötlete). 


\section{Gyermekirodalom: mese}

Téma: Közös meseolvasás; Kedves Állatkert!

Korosztály: 3. osztály

A tanulók a mesélő helyen, párnákon ülve vesznek részt a mese felolvasásában. A tanár, miközben olvassa a mesét, bevonja a tanulókat a tevékenységbe különféle feladatokat adva a tanulóknak: keressenek meg vagy számoljanak meg valamit a képeken, találgassanak, mi van a következő oldalon, mi lehet a szem elöl elrejtett helyeken, válaszoljanak kérdésekre, mondjanak a szövegben/rajzon megjelenőhöz hasonló példákat, az ismétlődő szövegrészeket mondják el közösen, a szövegben megjelenő új kifejezéseket játsszák el stb. (Kapás Krisztina ötlete).

\section{Gyermekirodalom: mese}

Téma: Közös meseolvasás; Hol van a kisbabám?

Korosztály: 3. osztály

A tanár a mesélést különféle feladatokkal készíti elö, a gyerekek párban egy szörnyikét rajzolnak, majd a mesélö helyen körbe ülnek, hogy meghallgassák a történetet. A mese közös elolvasása után a tanár arra kéri a párokat, hogy a mese különböző szörnyfigurái helyére ragasszák be saját rajzukat. Ezután újból megnézik a történetet, de most már a leíró részeket a saját rajzaikról készült leírással a párok helyettesítik be (Borók Lillian ötlete).

\section{Összegzés}

Az Európai Unióban az emberek igen fontos feladata az európai kultúrák megismerése és elfogadása. Ez a megismerni vágyás, a nyitottság, illetve nem utolsósorban a tolerancia terén kíván tőlünk változásokat. Minden népnek, amely csatlakozik az Európai Unióhoz, el kell fogadnia a másságot, az idegen kultúrát, és ehhez, az emberek közötti kommunikációhoz idegen nyelvek tanulására van szükség.

\section{Felhasznált irodalom}

Kovács Judit (2009): A gyermek és az idegen nyelv. Eötvös József Könyvkiadó, Budapest.

Kramsch, C. (1991): Culture in Language learning: A View from the United States. In: De Bot, K.,Ginsberg, R. B. \& Kramsch, c. (eds.), Foreign language research in cross-cultural perspective. John Benjamins, Amsterdam.

Laidlaw C. (2001): Intercultural Learning. Nemzeti Tankönyvkiadó, Budapest.

Mihály Ildikó (2001): A multikulturális nevelésről a világban. Új Pedagógiai Szemle, 51. 4. sz., $58-65$.

Nemzeti Alaptanterv, 2012. II. 3.2. Idegen Nyelvek, Magyar Közlöny, 2012/66, 46-47.

Tusa Cecília (é.n.): A multikulturális nevelés létjogosultsága és szükségessége az Európai Unióban.

URL: http://www.osztalyfonok.hu/cikk.php?id=217. Letöltés ideje: 2014. 07. 25. 


\section{Függelék}

\section{Rövidítések:}

$T$ - teacher

$L$ - learner

$\mathrm{Fw}$ - frontális munka

Gw - csoportmunka

$\mathrm{Pw}$ - pármunka

Iw - egyénimunka 


\section{Cats Sleep Anywhere}

Részletek a téma órai feldolgozásából

Téma: vers - Eleanor Farjeon: Cats

Korosztály/szint: 4. osztály/kezdő

\begin{tabular}{|c|c|c|c|}
\hline Activities & Language input & Groups & $\begin{array}{l}\text { Teaching } \\
\text { aids }\end{array}$ \\
\hline $\begin{array}{l}\text { Lead-in: What's in the bag? } \\
\text { T asks Ls to guess what she has in a bag. If } \\
\text { Ls can't guess they can ask T questions. } \\
\text { E.g.: } \\
\text { Is there a } \\
\text { When they have found the 'thing' from the } \\
\text { bag (a cat) T asks some questions about it. } \\
\text { E.g.: What color is it? What is it like? What } \\
\text { does it eat? Where does it live? What does it } \\
\text { like? Etc. } \\
\text { Introducing the poem: Cats } \\
\text { - T takes Ls for a 'walk' in the } \\
\text { classroom. When they get to a } \\
\text { picture of a sleeping cat T names the } \\
\text { place, Ls repeat the word. } \\
\text { - Then each L gets a word card and } \\
\text { finds the place it names and puts the } \\
\text { card there. } \\
\text { - Ls practice these phrases in different } \\
\text { ways: } \\
\text { - T asks Ls to repeat phrases by } \\
\text { throwing a ball. } \\
\quad \text { - T asks Ls to answer some question. } \\
\text { - T and Ls stand in a circle and pass } \\
\quad \text { picture cards around while they } \\
\text { repeat the phrases they can identify } \\
\text { with the pictures } \\
\text { Listening to the poem } \\
\text { Ls take the pictures and listen to T telling the } \\
\text { poem. When they hear the words that } \\
\text { describe their picture they raise it. } \\
\text { Ls sequence pictures on the board according } \\
\text { to the poem. } \\
\text { Reading the poem together } \\
\text { T and Ls read the poem together in different } \\
\text { ways } \\
\text { Homework } \\
\text { Makeillustrations to the poem }\end{array}$ & $\begin{array}{l}\text { Cats } \\
\text { Cats sleep, anywhere, } \\
\text { Any table, any chair } \\
\text { Top of piano, window- } \\
\text { ledge, } \\
\text { In the middle, on the } \\
\text { edge, } \\
\text { Open drawer, empty shoe, } \\
\text { Anybody's lap will do, } \\
\text { Fitted in a cardboard box, } \\
\text { In the cupboard, with } \\
\text { your frocks- } \\
\text { Anywhere! They don't } \\
\text { care! } \\
\text { Cats sleep anywhere. }\end{array}$ & $\mathrm{Fw}$ & $\begin{array}{l}\text { pictures of } \\
\text { a sleeping } \\
\text { cat put } \\
\text { down at } \\
\text { different } \\
\text { places in } \\
\text { the } \\
\text { classroom } \\
\text { word cards } \\
\text { ball } \\
\text { pictures } \\
\text { cards }\end{array}$ \\
\hline
\end{tabular}




\section{Professor Puffendorf's Secret potion}

Részletek a téma órai feldolgozásából

Téma: mese - Korky Paul and Robin Tzannes: Professor Puffendorf's Secret Potions Korosztály/szint: 5. osztály/ kezdő

\begin{tabular}{|c|c|c|c|}
\hline Time & Activities & Language input & Teaching aids \\
\hline $\begin{array}{l}1,5 \\
\text { mins }\end{array}$ & $\begin{array}{l}\text { Warmer leamers revise laboratory } \\
\text { vocabulary by naming things in a lab }\end{array}$ & $\begin{array}{l}\text { bottle, test-tube, potion, } \\
\text { machine, microscope, etc. }\end{array}$ & ball \\
\hline $\begin{array}{l}2 \\
\operatorname{mins}\end{array}$ & $\begin{array}{l}\text { Revision leamers label objects on a } \\
\text { picture of a laboratory and say statements } \\
\text { about it }\end{array}$ & $\begin{array}{l}\text { There is a -... There are -.- } \\
-\mathrm{s} \text { in the lab. }\end{array}$ & $\begin{array}{l}\text { big picture of a } \\
\text { lab word cards } \\
\text { blu-tack }\end{array}$ \\
\hline $\begin{array}{l}5 \\
\text { mins }\end{array}$ & $\begin{array}{l}\text { Lead-in groups of leamers solve a puzzle } \\
\text { ( } 3 \text { different puzzles), by doing the task } \\
\text { they can get the name of one of the } \\
\text { characters in the story }\end{array}$ & Crossword puzzles & worksheets \\
\hline $\begin{array}{l}3 \\
\text { mins }\end{array}$ & $\begin{array}{l}\text { Describing the characters } \\
\text { 1) groups of leamers select word cards } \\
\text { that characterize their 'chosen person' } \\
\text { from the story and put the cards around } \\
\text { the appropriate picture }\end{array}$ & $\begin{array}{l}\text { grumpy, whiskers, friendly, a } \\
\text { hat, clever, glasses, a } \\
\text { moustache, etc. }\end{array}$ & $\begin{array}{l}\text { Word cards blu- } \\
\text { tack } \\
3 \text { pictures }\end{array}$ \\
\hline $\begin{array}{l}1,5 \\
\operatorname{mins}\end{array}$ & $\begin{array}{l}\text { 2) Leamers listen to different statements, } \\
\text { the groups stand up when they can hear a } \\
\text { statement about their chosen character }\end{array}$ & $\begin{array}{l}\text { This person is lazy. This } \\
\text { person has got evil eyes. This } \\
\text { person wears glasses. etc. }\end{array}$ & \\
\hline $\begin{array}{l}6 \\
\operatorname{mins}\end{array}$ & $\begin{array}{l}\text { 3) Leamers make pairs, the pairs get two } \\
\text { statements on cards about one character, } \\
\text { they decide whether the sentences are true } \\
\text { or false, they display only the true } \\
\text { statements, the whole group checks, they } \\
\text { practise and check the describing } \\
\text { sentences by recognising the statements in } \\
\text { coded pattems, like: } \mathrm{C} \text { i f } \mathrm{f} \text {. Chip is } \\
\text { friendly. }\end{array}$ & & Word cards \\
\hline $\begin{array}{l}5 \\
\operatorname{mins}\end{array}$ & $\begin{array}{l}\text { 4) pairs describe another person, they } \\
\text { make sentences by sequencing given } \\
\text { words, they write the correct sentence on a } \\
\text { card and put their cardnext to the picture } \\
\text { of the character, the whole group checks, } \\
\text { leamers practise the description by 'slow } \\
\text { reveal' and a guessing game }\end{array}$ & $\begin{array}{l}\text { is / has got / likes / lives / } \\
\text { wears / etc. }\end{array}$ & $\begin{array}{l}\text { Task sheets } \\
\text { blank sheets felt } \\
\text { pens }\end{array}$ \\
\hline $\begin{array}{l}5 \\
\text { mins }\end{array}$ & $\begin{array}{l}\text { 5) pairs talk about the third character by } \\
\text { saying describing sentences using the } \\
\text { words from Activity } 4 / 1 \text {, some help can be } \\
\text { given }\end{array}$ & & $\begin{array}{l}\text { Word cards } \\
\text { helping words } \\
\text { on the board }\end{array}$ \\
\hline $\begin{array}{l}6 \\
\text { mins }\end{array}$ & $\begin{array}{l}\text { Follow-up leamers play a game, all cards } \\
\text { from } 4 / 1 \text { are put on the board face down, } \\
\text { groups choose a card and say a statement } \\
\text { with the phrase on it about one of the three } \\
\text { characters, if they can't say anything or are } \\
\text { wrong, the others can do the task }\end{array}$ & $\begin{array}{l}\text { Eg.: whiskers - Chip has got } \\
\text { whiskers. }\end{array}$ & $\begin{array}{l}\text { Word cards gid } \\
\text { on the board }\end{array}$ \\
\hline $\begin{array}{l}8 \\
\text { mins }\end{array}$ & $\begin{array}{l}\text { Making an interview groups of leamers } \\
\text { get the text of an interview with the } \\
\text { Professor cut into parts, they sequence the } \\
\text { parts, check the dialogue, } \\
\text { make pairs, pairs practise the dialogue }\end{array}$ & & $\begin{array}{l}\text { cut-up dialogue } \\
\text { blu-tack }\end{array}$ \\
\hline $1 \mathrm{~min}$ & $\begin{array}{l}\text { Homework } \\
\text { write about your favourite character }\end{array}$ & & exercise-book \\
\hline
\end{tabular}




\section{It's Halloween time!}

Részletek a téma órai feldolgozásából

Téma: Halloween

Korosztály/szint: 3. osztály/kezdő

\begin{tabular}{|c|c|c|}
\hline Time & Activities & Material \\
\hline $\begin{array}{l}4 \text { mins } \\
20 \text { mins }\end{array}$ & $\begin{array}{l}\text { Trick or treat - a rhyme } \\
\text { Ls revise a rhyme repeating it in different ways } \\
\text { according to T's instructions. Eg: Say it } \\
\text { slowly/fast/ happily/ angrily/ sleepily/etc. } \\
\text { Poem: Trick or treat, } \\
\text { smell my feet, } \\
\text { give me something good to eat!... } \\
\text { Halloween vocabulary games: 'Throw my } \\
\text { word back!' } \\
\text { T throws a ball to L1 and says a word, e.g.: } \\
\text { broomstick. L1 repeats the word and throws the } \\
\text { ball back. } \\
\text { Lip reading } \\
\text { T mimes saying a word without a sound, Ls guess } \\
\text { and say the word aloud. } \\
\text { Naming pictures } \\
\text { T reveals } 11 \text { pictures on the board and names } \\
\text { them together with Ls. } \\
\text { Passing on the pictures } \\
\text { Standing in a circle T and Ls pass the } 11 \text { pictures } \\
\text { around one by one. When a L passes a picture to } \\
\text { the next L, he/ she names it. } \\
\text { Guessing } \\
\text { T puts all the pictures face down on the board, Ls } \\
\text { guess each one. } \\
\text { What's missing? } \\
\text { T takes some pictures from the board while Ls } \\
\text { close their eyes, then Ls guess which pictures } \\
\text { were taken. } \\
\text { Collecting hidden word cards in the classroom } \\
\text { Ls search for the word cards which belong to the } \\
\text { pictures in the classroom. } \\
\text { Matching word cards and pictures } \\
\text { Ls read the words silently and match them to the } \\
\text { pictures. Ls read out the words with T's help. } \\
\text { Quick flash } \\
\text { T takes all the word cards off the board and } \\
\text { shows each one to Ls as fast as a flash. } \\
\text { Slow reveal } \\
\text { thing and guessing in pairs }\end{array}$ & $\begin{array}{l}11 \text { picture cards of the } \\
\text { Halloween words (witch, } \\
\text { skeleton, etc.) }\end{array}$ \\
\hline
\end{tabular}




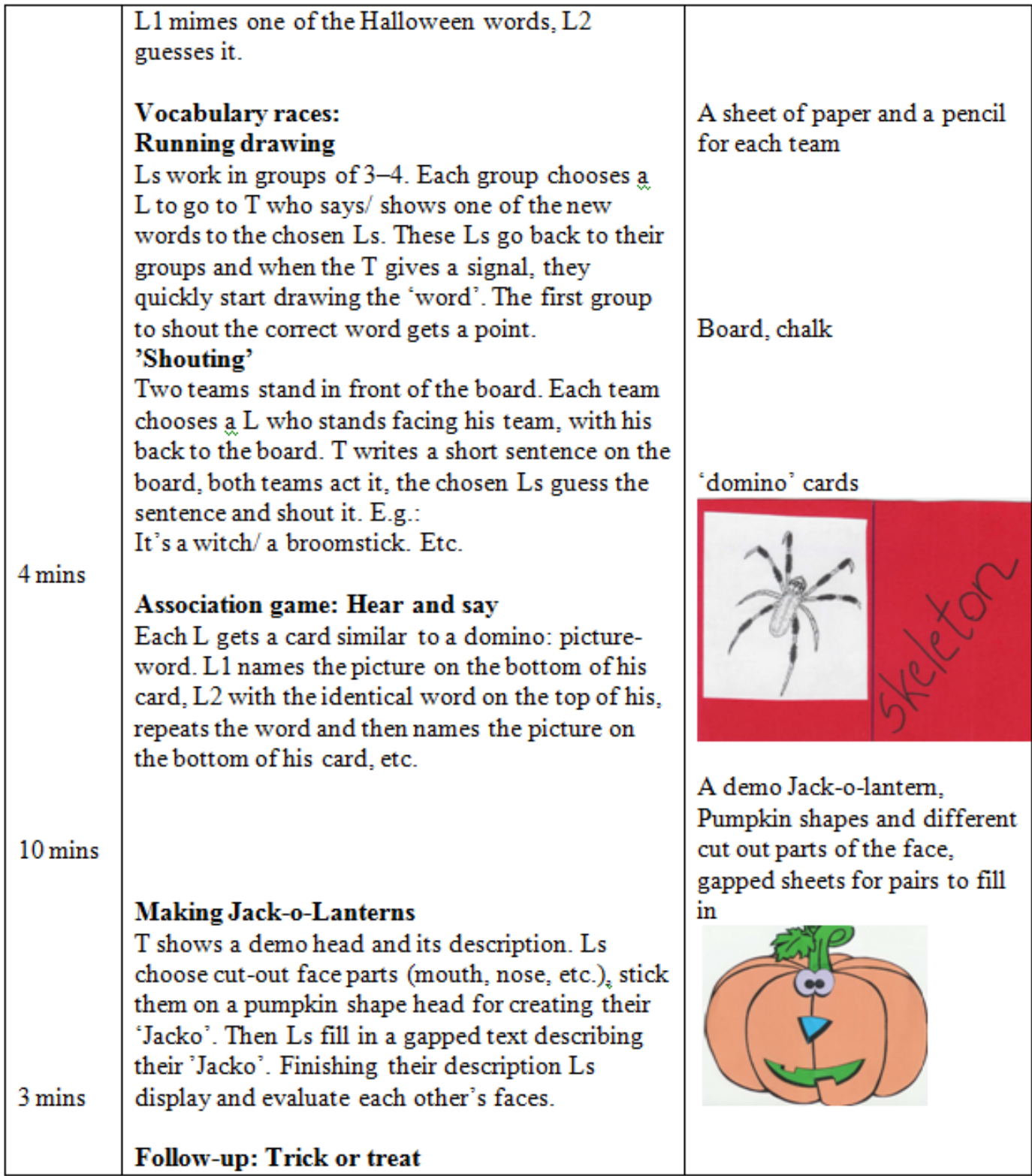

